\title{
Katarzyna Szymczyk, Opieka społeczna nad dzieckiem w Piotrkowie Trybunalskim w okresie Drugiej Rzeczypospolitej 1918-1939, Kontekst ogólnopolski, Wydawnictwo Uniwersytetu Jana Kochanowskiego w Kielcach, Filia w Piotrkowie Trybunalskim, Piotrków Trybunalski 2017, ss. 353 (rec. Małgorzata Marcysiak)
}

W 2017 r. ukazała się publikacja Katarzyny Szymczyk pt. Opieka społeczna nad dzieckiem w Piotrkowie Trybunalskim w okresie Drugiej Rzeczypospolitej 1918-1939, Kontekst ogólnopolski, będąca rozprawą doktorską przygotowaną pod kierunkiem dr hab. profesor UJK Joanny Majchrzyk-Mikuły, która została wydana przez Wydawnictwo Uniwersytetu Jana Kochanowskiego w Kielcach, Filia w Piotrkowie Trybunalskim.

Autorka jest historykiem i pedagogiem, pracuje w Filii UJK w Piotrkowie Trybunalskim. Pełni funkcję Dyrektora Instytutu Nauk Pedagogicznych, jest adiunktem w Zakładzie Historii Oświaty i Wychowania oraz Teorii Kształcenia.

Tytuł publikacji wskazuje na zainteresowanie problemem, który w wolnej już Polsce stawał się jednym $\mathrm{z}$ naczelnych zadań w opiece społecznej, jak stwierdza autorka (s. 12). Dlatego jej zamierzeniem było ukazanie systemu opieki na dziećmi w kontekście regionalnym, ale również porównawczym na tle ogólnopolskim.

Publikacja składa się z pięciu rozdziałów, które poprzedza wstęp, a zwieńcza zakończenie, bibliografia, streszczenie w języku angielskim i spis tabel. Ponadto na początku został zamieszczony wykaz skrótów, a na końcu wykaz wybranych towarzystw, instytucji i organizacji pomocowych funkcjonujących w Piotrkowie Trybunalskim w 1938 r., co stanowi swoiste ramy opracowania.

We wstępie autorka wprowadza w problematykę badawczą i uzasadnia jej wybór, przytaczając ponadczasowość oraz bezpośredni związek zagadnień pomocowo-opiekuńczych ze społeczno-gospodarczymi i politycznymi, jako jedną z przyczyn zainteresowania tematyką dziecka (s. 12). Wspomina też postaci, które tworzyły pierwsze 
koncepcje opieki nad dzieckiem u progu II Rzeczypospolitej. Należeli do nich m.in.: twórczyni polskiej szkoły pedagogiki społecznej - Helena Radlińska czy lekarz i pedagog Janusz Korczak.

Precyzując cele rozprawy, wskazuje w szczególności na przedstawienie potrzeb społecznych dzieci zamieszkałych w Piotrkowie Trybunalskim, analizę działalności organizacji społecznych, jak również ukazanie wkładu społeczników piotrkowskich $\mathrm{w}$ realizację zadań opiekuńczych. Niniejsze cele posłużyły do postawienia szczegółowych pytań badawczych.

Autorka opisuje źródła oraz w sposób przejrzysty i jasny prezentuje zastosowane metody badawcze, w których dominująca była metoda wyjaśniania historycznego oraz metoda porównawcza. Ponadto składa podziękowania za merytoryczne wsparcie, ale i za pomoc podczas poszukiwań i gromadzenia materiałów źródłowych.

Każdy z rozdziałów publikacji tworzy przejrzystą konstrukcję. Składa się z wprowadzenia, kilku wyodrębnionych, zatytułowanych podrozdziałów oraz podsumowania. Akapity składające się na poszczególne części charakteryzują się logiczną spójnością. Pierwszy rozdział ma charakter wprowadzający do całości dzieła. Przedstawia kształtowanie się systemu opieki nad dzieckiem w Polsce w kontekście publiczno-prawnym. Cytat Henryka Sienkiewicza zamieszczony na początku rozdziału trafnie prezentuje mentalność polskiego społeczeństwa przejawiającego gotowość do pomocy innym. Bezinteresowna działalność i podejmowane inicjatywy przyczyniły się bowiem do zorganizowania skoordynowanej opieki nad dziećmi w tym trudnym historycznie, gospodarczo i sanitarno-epidemiologicznie okresie. Efektywność działań mogła być podyktowana perspektywiczną myślą, która towarzyszyła inicjatorom, że właściwe warunki rozwoju dziecka pozwolą na odpowiedzialne pełnienie ról w dorosłym życiu (s. 30). Autorka bardzo wnikliwie wyjaśniła podejmowaną w pracy terminologię, odwołując się do wcześniejszych okresów, sięgając nawet do okresu średniowiecza w przypadku pojęcia opieka nad dzieckiem (s. 35). Większość odwołań znajduje się w przypisach, ale niektóre z nich, np. szpitale dla dzieci, zostały opisane w treści pracy (s. 39), co wykracza poza przyjętą przez autorkę cezurę czasową.

W rozdziale drugim autorka przedstawia problematykę opieki nad dzieckiem w okresie międzywojennym w badanym regionie, w kontekście państwowych i społecznych rozwiązań organizacyjnych. Przedstawia sytuację piotrkowskich dzieci, z uwzględnieniem warunków bytowych rodzin oraz organizację polityki społecznej na pozio- 
mie samorządowym. Opisuje funkcjonujące na terenie miasta placówki opiekuńczo-wychowawcze, działania organizacji pozarządowych, jak również udział związków wyznaniowych, zgromadzeń zakonnych i instytucji kościelnych w systemie opiekuńczo-wychowawczym, ukazując całościowy aspekt opieki.

Rozdział trzeci zawiera formy opieki nad dzieckiem sierocym. Autorka dokonała interesującej analizy, począwszy od sytuacji dziecka sierocego, przez prawodawstwo i organizację systemu w kontekście ogólnopolskim i regionalnym, aż do instytucji rodziny zastępczej jako jednej z form opieki, której rozwój nastąpił dopiero w latach 30 .

W rozdziale czwartym autorka przedstawiła problematyke opieki zdrowotnej nad kobietą ciężarną i dzieckiem, odnosząc się do badanego terenu. Dokonała wnikliwej analizy sytuacji higieniczno-zdrowotnej najmłodszych dzieci oraz instytucjonalnej opieki nad kobietą ciężarną, a także matką i dzieckiem. Dopełnieniem prezentowanych treści była działalność placówek zdrowotnych na rzecz dzieci oraz organizacja higieny szkolnej w Piotrkowie Trybunalskim w okresie międzywojennym.

W ostatnim rozdziale zostały opisane formy doraźnej działalności opiekuńczo-wychowawczej podejmowane przez piotrkowską społeczność, w tym akcje dożywiania czy organizacja letniego wypoczynku dla dzieci, takich jak kolonie i półkolonie. Przedstawiono również formy pomocy socjalnej, obejmujące np. pomoc materialną, zbiórki charytatywne, jak również akcje kulturalno-oświatowe organizowane na rzecz dzieci.

W zakończeniu autorka podsumowuje podjęte założenia badawcze, co pozwala jej na stwierdzenie, że w badanej społeczności lokalnej $\mathrm{w}$ okresie międzywojennym były podejmowane zintegrowane działania organizacji samorządowych, pozarządowych, charytatywnych oraz związków wyznaniowych i zgromadzeń zakonnych czy organizacji kościelnych na rzecz opieki nad dziećmi. Dowodem niniejszych działań były tworzone instytucje opiekuńcze, zdrowotne czy oświatowe, jak również ukierunkowanie polityki społecznej na potrzeby i oczekiwania w tym zakresie. Zdaniem autorki było to możliwe dzięki bogatym tradycjom opiekuńczo-wychowawczym piotrkowian (s. 319), ale i determinacji oraz gotowości do pomocy innym.

Publikacja posiada obszerne przypisy na dole strony, które zawierają nie tylko źródła, ale także mają charakter opisowy, co stanowi kompendium wiedzy w odniesieniu do omawianych pojęć i jest bardzo korzystne dla odbiorcy dzieła. Praca została opatrzona licznymi cytatami, które w wielu przypadkach są uzasadnione. Ponadto w publi- 
kacji znajdują się zestawienia tabelaryczne (s. 36), które porządkują prezentowane treści, co jest szczególnie cenne podczas porównywania danych źródłowych. Pozwala to na przejrzystość, a co za tym idzie czytelność opracowania.

Bogaty spis bibliograficzny zawiera źródła archiwalne, akty prawne, źródła urzędowe, materiały statystyczne, opracowania, spisy i sprawozdania urzędowe, jak również źródła narracyjne, czasopisma naukowe i popularno-naukowe o zasięgu regionalnym, ale także ogólnopolskim. Ponadto pamiętniki i wspomnienia, monografie i opracowania naukowe oraz źródła naukowe.

Bardzo staranna oprawa książki zachęca do zainteresowania się treścią publikacji. Okładka książki twarda, lakierowana, zaprojektowana przez Wydawnictwo, ma tematyczną szatę graficzną. Stanowi ją zdjęcie miasta, prawdopodobnie Piotrkowa Trybunalskiego, nieco rozmyte, w szarych barwach, stanowiące tło dla umieszczonego pośrodku przedniej okładki czarno-białego zdjęcia piotrkowskich dzieci, doskonale kontrastującego z tłem (brak źródła pochodzenia zdjęć). Ponadto na przedniej stronie okładki widnieje tytuł zapisany czcionką w wyróżniającym się czerwonym kolorze. Na tylnej stronie okładki znajduje się fragment recenzji wydawniczej prof. dr hab. Bożeny Urbanek.

Ciekawym dopełnieniem szaty graficznej są ryciny opatrzone rymowankami, które przedstawiają scenki z funkcjonowania przedszkola. Zatytułowane Zawsze lepsza tego dola - kto uczęszcza do przeszkola, zachęcają do skorzystania z usług tej instytucji. Ryciny zostały zamieszczone na wewnętrznej stronie przedniej i tylnej okładki.

Publikacja stanowi cenne źródło na rynku wydawniczym, które ze względu na złożoną problematykę skupioną wokół dziecka może zainteresować szerokie grono odbiorców. Jest bowiem adresowana nie tylko do historyków i pedagogów, ale także medyków, psychologów, socjologów, jak również do wszystkich, którym los dziecka nie jest obojętny. Ze względu na wspominaną przez autorkę ponadczasowość jest lekturą nieprzemijającą w swojej problematyce, dlatego może być źródłem inspiracji do podejmowanych działań na rzecz poprawy sytuacji dzieci w dłuższej perspektywie. 